\title{
Legal Activism or Class Action?
}

The political economy of the "no boss" and "no labour relationship" in China's construction industry

Pun Ngai and Xu Yi

\section{(2) OpenEdition \\ Journals}

Electronic version

URL: http://journals.openedition.org/chinaperspectives/5542

DOI: 10.4000/chinaperspectives.5542

ISSN: 1996-4617

Publisher

Centre d'étude français sur la Chine contemporaine

\section{Printed version}

Date of publication: 30 July 2011

Number of pages: 9-17

ISSN: 2070-3449

\section{Electronic reference}

Pun Ngai and Xu Yi, «Legal Activism or Class Action? », China Perspectives [Online], 2011/2 | 2011, Online since 30 June 2014, connection on 28 October 2019. URL : http://journals.openedition.org/ chinaperspectives/5542; DOI : 10.4000/chinaperspectives.5542 


\title{
Legal Activism or Class Action?
}

\author{
The political economy of the "no boss" and "no labour relationship" in China's construction \\ industry
}

\author{
PUN NGAI AND XU YI*
}

\begin{abstract}
This article aims to study an issue of "double absence" embedded in the rapidly changing construction industry and to explore how it induces serious collective action among construction workers in post-socialist China. $\left({ }^{* *}\right)$ The political economy of the construction industry has shaped a specific labour use system - a labour subcontracting system. The system generates a specific capital-labour relationship in which the legal labour identity and labour relationship are highly subsumed by an "absent" employer. It creates a double absence in legal terms: an "absent" boss and an "absent" labour relationship. This double absence has led to a perpetual process of wage arrears and struggles by construction workers to pursue delayed wages in various ways, usually involving legal action or non-legal collective action. The findings of this study are drawn from case studies conducted between 2008 and 2009 in seven Chinese cities. The labour struggle - the fight for delayed payment - was understood not as a form of legal labour activism, but as incipient class action in a specific context.
\end{abstract}

KEYWORDS: legal activism, class action, labour subcontract system, Chinese construction workers

\section{Introduction}

A global China is made spatially possible by Chinese construction workers, comprised of more than 40 million peasant workers hailing from all parts of China's countryside. Recent years have seen increasing numbers of individual and collective actions among construction workers pursuing delayed wages or demanding compensation for injury or death. These actions include legal litigation, such as suing subcontractors or companies, as well as collective actions such as property damage, physical assault, and even suicidal behaviour. Could these legal and collective actions be understood as class actions, especially when framed by a discourse of human and legal rights? What is the relationship between legal action (supposedly a realm of civil society) and collective resistance (supposedly an area of class conflict driven by production relations)? In the area of labour consciousness, how could workers make sense of their actions, both legal and/or collective, and negotiate with a hegemonic discourse? Do they transform legal action into class action at a particular juncture and thereby transgress the construed hegemonic language of legal rights? Addressing these questions requires an understanding of the political economy of the construction industry that shapes the politics of labour resistance among migrant construction workers. The first part of this paper discusses changes in the political economy of the construction industry and the rise of the labour subcontracting system that results in a "double absence" - the absence of a boss and management and of a capital-labour relationship in the Reform period. The second part focuses on how this "double absence" generates a variety of legal and collective actions among construction workers, and how the workers take and understand their actions.

The rapid development of the construction industry and accompanying structural changes has led to the rebirth of a highly exploitative labour subcontracting system that was abandoned during the socialist period. (1) This labour system embodies two processes: the rapid commodification of labour through non-industrial social relations organised by a quasi-labour market in rural villages; and the subsumption of labour in the production process of the construction sector in the urban areas. These two processes have shaped a specific labour subcontracting system in China under reform, resulting in a perpetual process of wage arrears and the struggle of construction workers to pursue delayed wages in various ways, usually involving violent collective action. (2)

China's construction industry has experienced astonishing growth in the world market in recent years. ${ }^{(3)}$ By 2007, the Chinese construction industry was consuming half of the world's concrete and a third of its steel for building its global cities, and was employing more than 40 million workers, most of them peasant-workers from all parts of the country. About 30 percent of all migrant workers from the countryside work in the construction industry. ${ }^{(4)}$ In order to transform Beijing, Shanghai, and Guangzhou into China's core global cities and speed up the process of urbanisation, China has invested about $\$ 376$ billion in construction each year since the Tenth Five Year Plan (2001-2005), making construction the country's fourth

Pun Ngai is Associate Professor in the Department of Applied Social Sciences, Hong Kong Polytechnic University; Xu Yi is a PhD Candidate in the Department of Applied Social Sciences, Hong Kong Polytechnic University.

** We are grateful to Lu Huilin, Li Da Jun, Liang Zicun, Zhang Huipeng, Zhou Li Juan, and Li Qing Su, who provided unfailing research support. We are also grateful for financial support from two research grants, "Working Class Community: Space and Labour Resistance in China" and "The Making of Transborder-community in the Pearl River Delta," Department of Applied Social Sciences, Hong Kong Polytechnic University.

1. See Lei Guang's study on the home renovation industry in the late 1990 s and early 2000 s, which is one of a few but significant studies relating to construction workers. Lei Guang, "The Market as Social Convention: Rural Migrants and the Making of China's Home Renovation Market," Critical Asian Studies, vol. 37, no. 3, 2005, pp. 391-411. See also Shen Yuan, Shichang, jieji yu shehui (Market, class and society), Beijing, Social Sciences Academic Press, 2007, pp. 216-269.

2. Pun Ngai and Lu Huilin, "A Culture of Violence:The Labor Subcontracting System and Collective Actions by Construction Workers in Post-Socialist China," The China Journal, no. 64, 2010, pp. 143-158.

3. In China, the construction industry is defined as the sector that creates buildings and other structures. See Sun Sheng Han and Ceorge Ofori, "Construction industry in China's regional economy, 19901998," Construction Management and Economics, vol. 19, 2001, pp. 189-205.

4. See "Construction Workers Alienated," China Daily, 9 July 2007. 


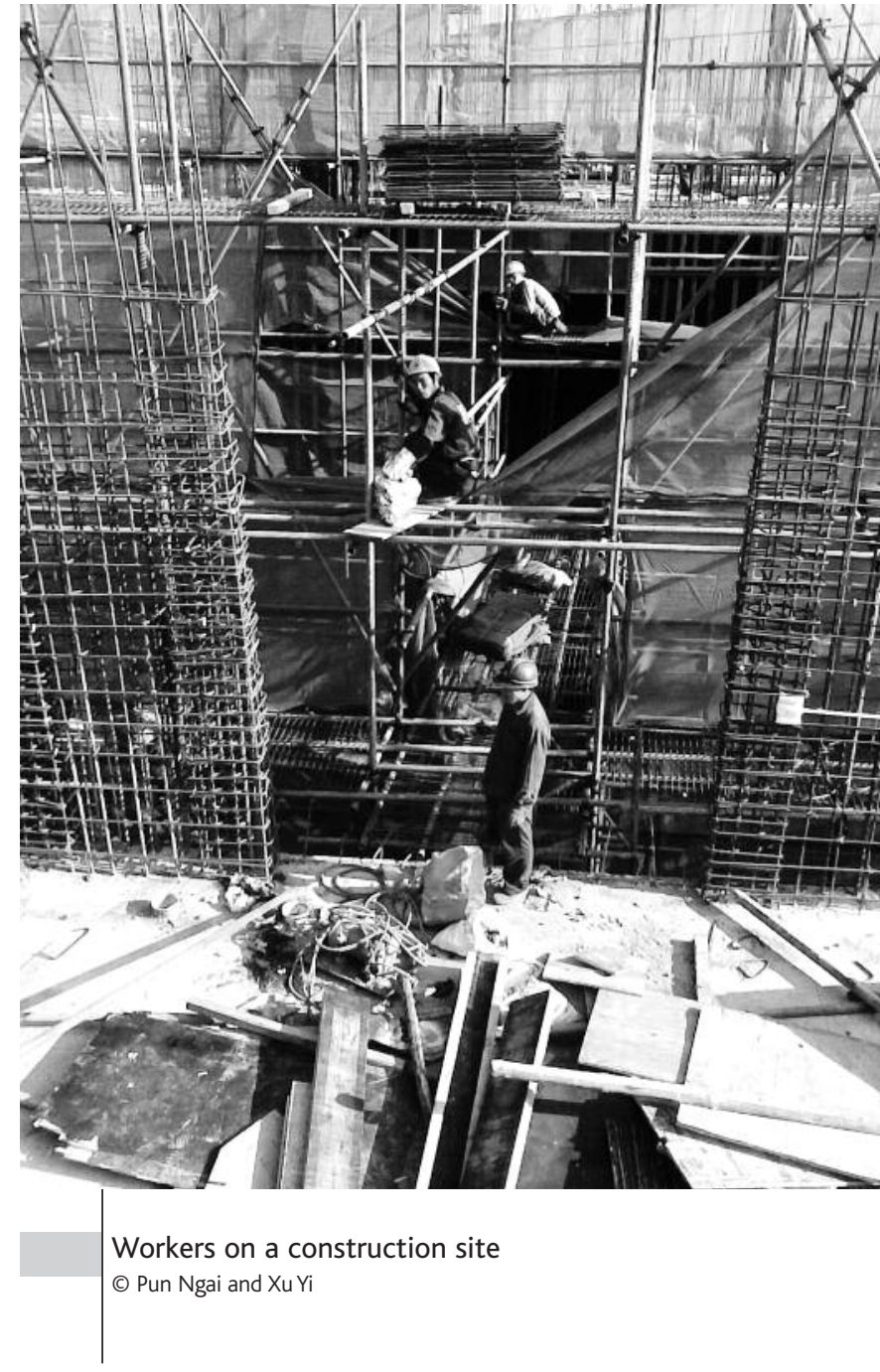

largest industry. By the turn of the twenty-first century, the construction industry had become a strategic industry accounting for approximately 6.6 percent of China's GDP. By the end of 2007, the industry's total income had risen by 25.9 percent to RMB 5.10 trillion, and total output value reached RMB 2.27 trillion in the first half of 2008. (5) $^{5}$

This study draws on research conducted in seven cities - Beijing, Shenyang, Chengdu, Guiyang, Wuhan, Changsha, and Guangzhou - in 2008 and 2009. More than 1,500 supervisors and workers were interviewed on 12 construction sites in these seven cities. In January 2009, the study followed workers back home to a rural village in Tang County, Hebei Province, where more than 1,500 working adults out of a population of 6,000 were construction workers. In the village we further understand the social origins of the labour subcontracting system and how it served as the bedrock for collective action among the migrant construction workers.

It became clear to the research team that in contrast to the enormous gross profits and output value of the construction industry, construction workers remain a badly protected Chinese working class. ${ }^{(6)}$ We were also struck by the violent individual or collective action taken by workers. The working lives of construction workers involved acts of individual and collective conflict, attempts to damage buildings, physical assault, and even suicidal behaviour. At the construction site we observed a variety of violent actions that were no doubt engendered by changes in the history and political economy of the industry.

\section{The labour subcontracting system}

A socialist structure of the Chinese construction sector was radically transformed during the Reform period. The Deng era reforms, accompanied by a discourse of modernity, paradoxically brought an end to the "socialist" and "modern" practices of the construction industry. The year 1980 marked the beginning of the end of the planned economy in industry, and the resumption of the bidding and contract system in the construction industry. (7) A World Bank project, Lubuge Hydropower in Yunnan Province, radically changed socialist practices in the construction sector through the use of international competitive bidding in 1980. This represented the launch of changes in the nature of capitalisation of the industry. As early as 1978, Deng Xiaoping pointed out that the construction industry could be profitable. The reform objectives set for the construction industry included restructuring the industry's administrative system; opening construction markets; granting autonomy to state-owned enterprises; establishing a competitive bidding system; and improving project managerial skills. ${ }^{(8)}$

As the pioneer industry undertaking a series of reform programs, the construction sector was the first to introduce "capitalistic" market mechanisms into its operations. In 1984, the State Council promulgated a regulation stating, "State-owned construction and installation enterprises shall gradually reduce the number of fixed workers. In the future they shall not, in principle, recruit any fixed workers except skilled operatives necessary to keep the enterprise technically operational." (9) Another significant 1984 regulation, the "Separation of Management from Field Operations," stated that general contractors or contracting companies should not directly employ their blue-collar workforce. ${ }^{(10)}$ Rather, they should employ labour subcontractors who were to be responsible for recruiting the workforce. Needless to say, the regulations initiated an abrupt change in the capitalisation as well as the management of the construction industry and the composition of its workforce, leading to problems in the labour subcontracting system that became evident in the latter stage of reform. Driven by state initiatives, construction enterprises were further marketised, and field operations were alienated from direct management via the labour subcontracting system.

By the late 1990s, the restructuring of the capital-labour relationship in the construction industry was almost complete. ${ }^{(11)}$ While this series of dramatic changes arguably increased efficiency and productivity in the operation of construction projects, a direct result was the emergence of a

5. See Zhongguo jianzhu nianjian, 2008 (Statistics of China's Construction 2008), Guojia tongji chubanshe.

6. "Badly protected working class" refers to work conditions such as intensity, hours, and payment methods, but not necessarily the pay rates of construction workers compared with workers in the manufacturing or service sectors.

7. See also Lei Guang, op. cit., 2005, pp. 391-392.

8. See R.E. Mayo and G. Liu, "Reform Agenda of Chinese Industry," Journal of Construction Engineering and Management, vol. 121, no. 1, 1995, pp. 80-85

9. This was the "Tentative Provisions for Construction Industry and Capital Investment Administration System Reform." See Xin Zhongguo jianzhu ye wushi nian (Fifty years of New China's construction industry), Beijing, Zhongguo sanxia chubanshe, 2000, pp. 7-8.

10. See the Construction Ministry's report on Xin Zhongguo jianzhu ye wushi nian (Fifty years of New China's construction industry), ibid., p. 8.

11. In August 1995, the State Planning Commission, the Ministry of Power Industry, and the Ministry of Transport jointly issued "The Circular on Granting Concession to Foreign Financed Capital Projects." The Construction Law was put into effect on 1 March 1998, covering a wide range of issues such as qualifications for entry into the construction industry, procurement and delivery of work, construction supervision, construction safety, construction quality, legal liability, market regulations, and procedures in construction projects. 
Property Developer

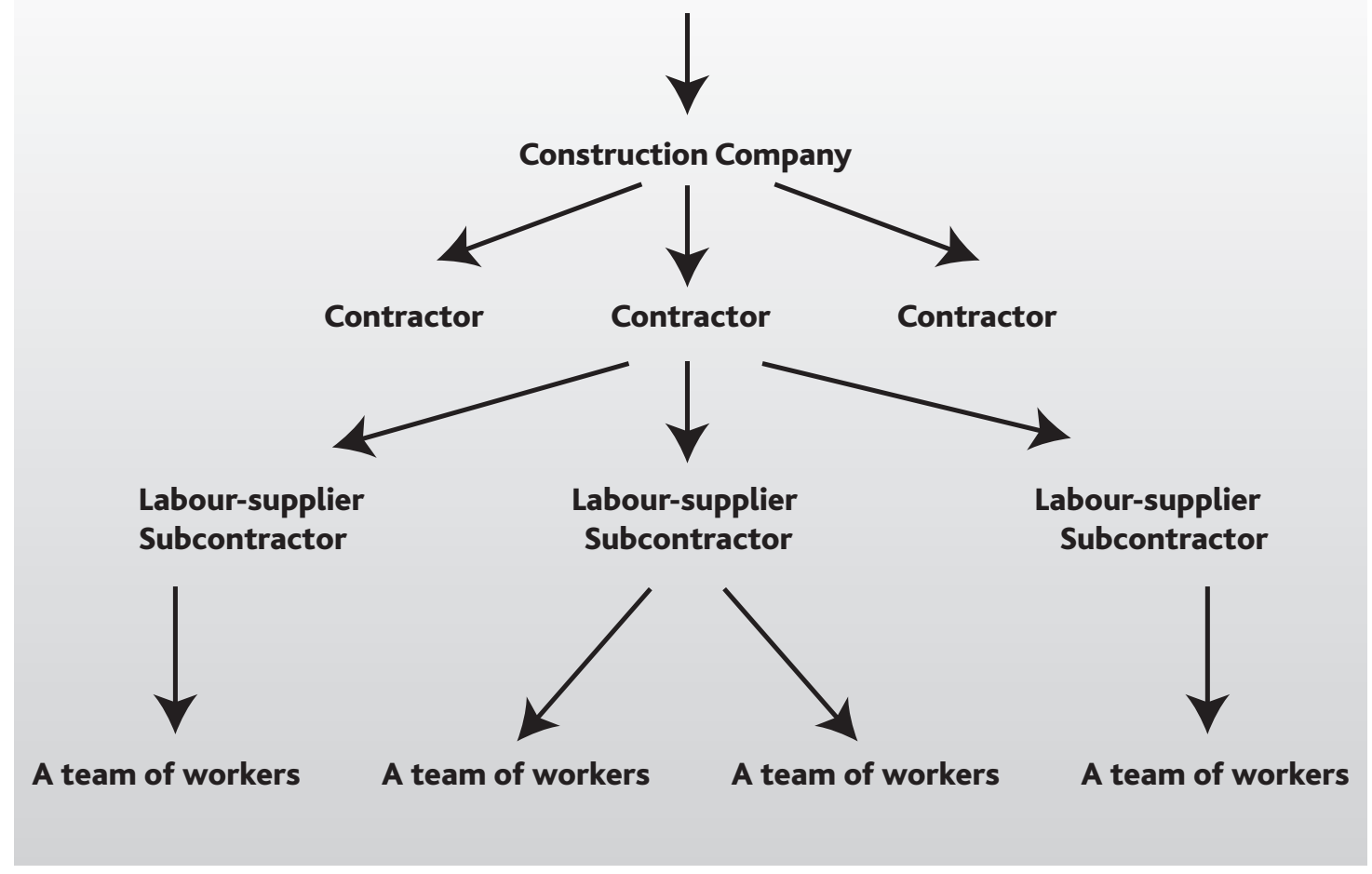

equipment arrangements for its contractors. In the first tier of subcontracting process in the construction industry, it is highly monopolized by the stateowned companies because of their strong foothold in the industry. This state-owned company usually has a numbers of contractors coming from all over the country. These contractors are called dabao (大包), big contractors responsible for providing raw materials and labour for the project. Sometimes these contractors will set up a labour service company to help recruit rural labourers, but in reality

multi-tiered labour subcontracting system. Today, irrespective of the location of construction projects and the form of capitalisation, be it through a state-owned or privately-owned company, the labour contracting system is the most significant form of labour in the industry. Organised through a subcontractor who recruits a team of peasant-workers from rural areas to work on construction sites, more than 40 million workers are now part of this labour subcontracting system. ${ }^{(12)}$

Looking deeply into the labour process of the industry, we see that a double delinking of capital and industry and of management and production created a power imbalance in the production chain more favourable to the top-tier contractors. In the production chain, the top-tier contractors control construction projects through their relationship with property developers and the local state while they at the same time outsource their work to lower-tier subcontractors. In this hierarchical structure, the toptier contractors, without contributing substantial capital to the construction operation, seek to profit from the transfer of investment risk and labour recruitment to their subcontractors. "They don't bother to get their hands dirty. They transfer all the risks to us. They make us face the workers at times of wage arrears when the money doesn't arrive from above," said Lao Fung, a third-tier subcontractor. This was the most frequent complaint against top-tier contractors that we heard from labour-supply subcontractors at the construction sites.

Let us take a typical construction project in Beijing or Guangzhou as an example. The subcontracting system usually began with a giant property developer responsible for land reclamation and the architecture and design of the villa project. This property developer can be state-owned or privately owned enterprise. The actual construction was shifted down the production chain through a bidding process to a construction company, which is often a state-owned company that only took charge of project they relied on labour-supply subcontractors (xiaobao 小包 or qingbao 清 包) to recruit labour, manage daily work assignments, and pay out wages upon completion of the project. In return, these subcontractors further depended on their labour-use facilitators, daigong (带工), usually their relatives or co-villagers, to recruit workers from their own or surrounding villages. In this way, construction workers were organised into a number of small subcontracting teams that worked on the construction site for this project. The number of workers in each subcontracting team ranged from a dozen to a hundred.

The construction projects that we studied in the Beijing migrant community brought very low profit margins for subcontractors, who often lacked sufficient funds to tide them over until their final payment. The task was to build 108 villas of 300-500 square meters. Lao Fung, an experienced subcontractor, provided us with detailed information: to build a block of villas with an estimated sale price of about RMB 10 million, the bidding price was only RMB 760,000 (including the costs of raw materials, labour, and administration) for the first-tier contractors, who out-sourced the construction work to second-tier contractors, who further subcontracted the work to labour-supply subcontractors. The standard unit price set for labour costs was RMB 80,000, which meant that third-tier and fourth-tier labour-supply subcontractors had only this lump sum from which to pay the workers they recruited and to make a profit. Lao Fung explained, "We almost lost money in building the villas. ${ }^{(13)}$ Sometimes we run up debts but still have to keep ourselves in the production chain, otherwise we'll be

12. The number of peasant-workers in the industry is listed in a 2004 ACFTU report, "A Survey on the Situation of Construction Peasant-Workers." See http://finance.sina.com.cn/g/20041111/ 17381148918.shtml.

13. The structure of villas is more complicated than for a high-rise, requiring subcontractors to contribute more labour days to completion of the work. 
left out." Coming from places such as Hebei, Anhui, Sichuan, and Shandong, most contractors and subcontractors had little bargaining power with the construction companies, which were mainly from big cities such as Beijing and Guangzhou and were often transformed state enterprises well connected with municipal administrations. Contractors and labour subcontractors often faced serious arrears even in the modest payments owed to them at the early stages of construction, and they were in a weak position to stand up for themselves against locally influential developers and construction companies. All these factors combined to make wage arrears an intractable and unresolved problem. ${ }^{(14)}$

\section{The subsumption of labour in the production process}

China's rapid urban and industrial development and the further expansion of the construction industry in the 1990s was accompanied by a tremendous demand for cheap labour. The labour subcontracting system subsequently stood out as the single greatest means of labour expropriation, laying the foundation for the subsumption of labour in the production process in its specific form. According to Marx, there are two forms of the subsumption of labour under capital, i.e., the formal subsumption of labour and the real subsumption of labour. (15) Today's labour expropriation in the construction industry can be considered a form of formal subsumption of labour, under which the labour power of construction workers is subsumed by the manipulation of capital through the labour subcontracting system. In addition to the valorisation of surplus value for capital, it also creates the following effects: further separation of means of production from construction workers, prolonged reliance on subcontractors to recruit labour, the absence of a direct capital-labour relationship, small-scale production organised under small subcontracting teams, and last but not least, the perpetual process of wage arrears.

In China, the subsumption of labour in its specific form was not only a product of industry restructuring, serving the process of capital accumulation, but was also a joint creation of state and capital - because it was the state that took the lead in changing ownership and management-labour relations in the industry by ordering the construction industry to rely on subcontracting, and by turning state-owned enterprises into profit-making corporations.

In the late 1990s, the development of the labour market working via the labour subcontracting system left the rural workforce with no state or social protection. Workers had no health coverage, and no casualty insurance or disability payments. By the end of the 1990s, subcontractors were recruiting peasant-workers as casual labourers who were not even provided with a legal contract as required by the Labour Law of 1995. ${ }^{(16)}$ None of the construction workers we've interviewed up to now has received regular monthly payments, and not one has signed a labour contract. Although the new Labour Contract Law came into force in January 2008, neither contractors nor subcontractors observe the new law, and only a few workers were aware of the new legal obligations binding contractors. Workers typically responded to our questions by saying, "What's a labour contract? No, we don't have it. I've never heard of it."

All of the workers we interviewed in Beijing, Shenyang, Chengdu, Guiyang, Wuhan, Changsha, and Guangzhou from December 2007 to January 2009 had been promised a daily pay rate ranging from 50 yuan to 120 yuan, depending on the type of job and the skills required. (17)
Notwithstanding the promised pay rate, it will be observed that workers run a significant risk of ultimately being paid at a substantially lower rate, as well as a significant risk of never being paid at all, and without contracts they have very limited recourse to the courts. This failure of the state to provide legal and social protection to peasant-workers has reduced legal reforms to little more than lip service.

The growing incidence of non-payment of wages is a case in point. Since developers do not pay contractors and sub-contractors until after the project is completed, the workers are penalised by delayed payments - and as will be seen, this puts them at great risk. Instead of weekly or monthly wages, until the completion of the project or the end of the year construction workers are usually paid an irregular "living allowance" (生活费shenghuo fei) arranged by their labour-supply subcontractors, which is barely enough to cover food and other daily expenses. The allowance ranges from 100 to a few hundred yuan per month (about 10 to 20 percent of their promised monthly income), depending on the quality of the subcontractor.

Many subcontractors had to use their own money to provide a living allowance for their workers. Some workers received no living allowance at all because their subcontractor claimed to have no money. The subsumption of labour value in the production process was made possible when wages were replaced by living allowances and when subcontractors justified this practice by claiming a lack of funds for labour costs from their contractors. In the first day of 2008 Beijing was numbingly cold, and most of the construction sites were already idle. In a shack on the outskirts of the metropolis, Lao Chen, a 50-year-old Hubei worker was waiting anxiously to receive his wages from the subcontractor. As we gathered round him in the cold, Lao Chen opened his record of the past year's work, showing meticulously how he had worked 286 consecutive days with neither a day off nor a penny to show for it. In his dorm at a construction site, he explained,

We're not even workers. Workers sell their labour to the boss and in return they receive wages.... But as construction workers, we're different! I've been working 286 days for the boss and I still can't get my pay. I am waiting for my gongqian [工钱 - working money] ${ }^{(18)}$ just as I'm always waiting for my luck.

14. Pun Ngai and Lu Huilin, art. cit., pp. 149-150.

15. According to Marx's Economic Manuscripts of 1861-1863, the form that produces absolute surplus value is called the formal subsumption of labour under capital. It is distinguished only formally from other modes of production in which the actual producers provide a surplus value, i.e., work more than the necessary labour time, but for others rather than for themselves. The real subsumption of labour under capital is developed in all forms that produce relative, as opposed to absolute, surplus value. With the real subsumption of labour under capital, Marx argued, a complete revolution takes place in the mode of production itself, in the productivity of labour, and in the relation - within production between the capitalist and the worker, as well as in the social relationship between them.

16. The 1995 Labour Law was supposed to lay a foundation for workers' legal and contractual rights, and for a system for resolving labour disputes. In the 2000s, the Beijing leadership began to channel labour disputes into arbitration committees and the court system through bureaucratic and legal procedures. The Labour Contract Law, which went into effect on 1 January 2008, is considered the most significant change in Chinese labour law in the Reform period. See http://www.gov.cn/ziliao/flfg/2007-06/ 29/content_669394.htm.

17. Women workers were paid 5 to 10 yuan less each day than their male counterparts on the same job. Pay rates reached a peak in 2007 and 2008 due to the shortage of labour that became evident in the early to mid-2000s. In 2006, the daily pay rates for cement pourers and carpenters were 30 yuan and 50 yuan respectively, and they soared to 50 yuan and 100 yuan in 2008.

18. In the construction industry, workers used the term gongqian (工钱 - work money) to describe their wages. But in the manufacturing and service sectors, workers usually used gongzi (工资 - work payment), a more formal concept referring to wages. Congzi means wage, and it bears a formal capitallabour relationship, but the term gongqian does not have the same connotation. 


\section{Who is my boss?}

The rapidly changing social relations in rural areas further fuels problems and conflicts derived from a labour subcontracting system that was supposed to operate through kin and ethnic networks. The research team was in a village in Tang County, Hebei Province, in the first week of January 2009. As in most Hebei villages, a major share of family income relied on earnings from daigong, working outside the village, especially in the construction industry. It was not a particularly poor village, with an average annual family income of around RMB 15,000 to 20,000. We visited more than 30 families that had one or more members working on construction sites in Beijing. Having a long tradition in the construction industry, most families had a father and son, that is, at least two generations, working in the sector. These families were keen to show us their "papers of debt" that they had collected over the years, each telling a story of unpaid toil. One case of unpaid wages that we observed in the village was more than five years old: a 45-year-old man, Hai, who had worked continuously in the construction industry for ten years, showed us a piece of worn paper that stated "XXX owes Hai 3,000 yuan only." The debtor had signed it, making the paper evidence of a debt owed to the worker. In this village, most labour supply subcontractors recruited from their own or surrounding villages.

Every time we encountered cases of debt, we enquired into the debt and the reasons for non-payment.

\section{- "Do you mean the subcontractor intentionally kept your money, or he couldn't pay you because the money didn't come through?" we asked. \\ - "Who knows? We didn't know who the boss was. We haven't even seen the boss," the worker usually would say.}

The boss the workers referred to was not the labour-supply subcontractor, but the second or third-layer contractor who out-sourced the work to the labour-supply subcontractor. The subcontractor was the only target for seeking wage payment because it was he who had recruited the workers, even though he was not the boss in a legal sense. ${ }^{(19)}$ At the beginning of the Chinese New Year, the subcontractor would use his network in the village to recruit a group of workers, the exact number depending on the size of the construction project, and he would promise the workers a daily pay rate. All of the workers knew that their wages would not be paid until the completion of the construction project or the end of the year, a practice that had already become routine in the village. As long as their wages were received by the time they returned home to help with the harvest, or by the end of the Chinese New Year, workers consented to this payment delay, although not altogether willingly. In this sense, labour as a commodity value is not reliant on legally required standards or accepted norms in society at large. This commodification process was special in that non-industrial social relationships were manipulated to serve the purpose of labour expropriation while at the same time helping to disguise the wage-labour relationship with capital. The "real" boss has become something of a myth in China's present construction industry.

Construction workers' trust that they would be paid regularly was based on kin and co-villager networks. In the construction industry, workers were led to believe that their subcontractor, as their relative or co-villager, would not run away with the money. According to a saying popular among

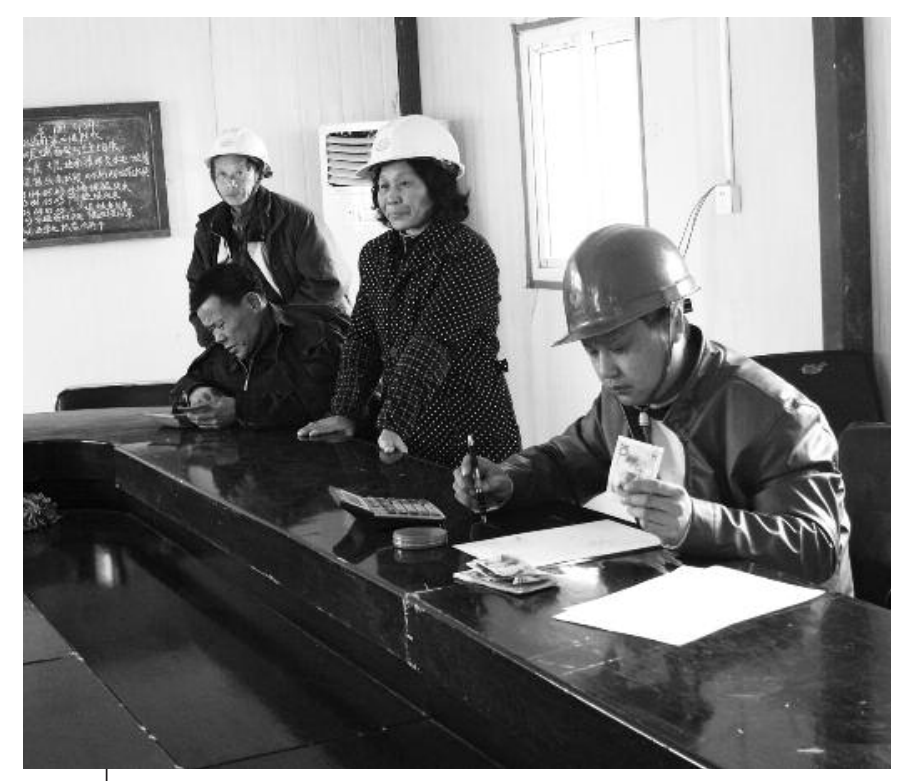

Labour arbitrage concerning salaries (๐) Pun Ngai and XuYi

the workers, especially the older generation, "A monk may run away but a temple stays." This means that the subcontractor still had a family in the village, and it was difficult for the whole family to run away. This faith was destroyed, however, when wage arrears and debt became routine in the late 1990s. The rapid commodification of labour in the rural community through labour-supply subcontractors has eroded trust. ${ }^{(20)}$

A number of workers emphasised their constant search for a new small subcontractor that would be better than the previous one. The reason for this practice was clear to us: no one was trusted enough in the village anymore. But in times when jobs were badly needed, middle-aged workers in particular had little choice of subcontractors. Even if the subcontractor had a poor record of wage payment, there was still hope that he would be able to pay at the end of the Lunar Year.

We observed tense human relations in Hebei's rural villages, with serious worries and anxieties among workers that wages would not be paid and that subcontractors, either relatives or co-villagers, would run off. Trust had been destroyed, and normal human relationships were somewhat distorted. As middle-men with personal networks who fed the construction industry with cheap labour, subcontractors were the main agents in the process of commodification of labour. Rural non-industrial social relationships were manipulated to serve the purposes of labour subsumption, which in turn intensified hidden social conflicts on the construction site and in the village.

\section{Legal action or class action?}

The political economy of the construction industry has shaped a specific labour use system - a labour subcontracting system - that generates a

19. Strictly speaking, according to the Company Law and the Construction Law, labour-supply subcontractors do not have corporate status and hence do not have a legal status to employ workers.

20. This finding contradicts Shen Yuan's study on construction workers, which argues that kinship and covillage relationships among the workers were able to construct a relation-hegemony in which the workers' interests were disguised. See Shen Yuan, Shichang, jieji yu shehui (Market, class, and society), Beijing, Social Sciences Academic Press, 2007, pp. 216-269. 
specific capital-labour relationship in which the legal labour identity and labour relationship are highly subsumed. It creates a double absence in the legal sense: an "absent" boss and an "absent" labour relationship. This double absence has led to a perpetual process of wage arrears and the struggle of construction workers to pursue delayed wages in various ways, usually involving collective action. What is interesting to us is that even since the issue of "double absence" has surfaced as a legal problem, few labour disputes have actually reached the courts through formal legal procedures. Instead, most labour disputes, following a series of labour actions, have been settled through informal legal channels, especially through direct negotiations that often involve violent struggles with the construction company.

Collective actions by construction workers have centred largely on wage arrears and injury compensation. Under an unreasonable labour subcontracting system, construction workers have gradually learnt that their labour rights can hardly be protected. Unlike the studies by Lee (21) and Gallagher, ${ }^{(22)}$ which emphasised legalism regarding the labour rights of Chinese migrant workers, our study found that few construction workers attempted to take action through litigation or even labour arbitration. Most workers launched direct individual or collective actions against construction companies or put pressure on local governments. The reason for this, paradoxically, is also the "double absence" of the boss and the capitallabour relationship in a legal sense.

The workers usually did not take action until the bottom line of their consent - receiving wages at the end of the Lunar Year - was broken. Once action was taken, it was often of a violent nature, involving fighting, physical injury, suicidal behaviour, or attempts to damage buildings.

On a freezing winter's evening in January 2008, we met Lan and her coworkers in the workers' dorm of a construction site in Beijing. Work had ended a few days earlier, but workers' wages had not arrived, leaving workers waiting anxiously to return to their hometowns. Lan and her co-workers, from a village in Hebei, were arguing with their subcontractor, who was trying to convince the workers to wait patiently for their payments. The argument was so loud that it attracted workers from other dorms to gather around.

"You have to give us justice, (公道 - gongdao); working for no money is simply against the law of heaven," one worker said.

"We trusted you and we relied on you to chase up our money - our money tainted with blood and sweat! Keeping our wage is against the law (违法 - weifa) !" another worker followed.

During the argument with the subcontractor, workers often used the terms gongdao (the principle of justice) and weifa (against the law).

The language the workers learned to claim their rights originated in the central government's discourse of legal labour rights. In order to alleviate the industrial tensions engendered since the 1990s, the Chinese government has issued a series of labour regulations and laws, not only to protect labour rights but also to resolve social conflicts between capital and labour. "Rule by law" has become not only a slogan of contemporary Chinese society but also a means of political legitimacy for the Chinese partystate. (23) It also represents a process of de-politicisation (de-ideologisation) of the party-state in its attempts to regain political hegemony through a legal rationale. Hence an imagined "irrational" ideological society in the socialist period is replaced by a "rational" legal society in the re-

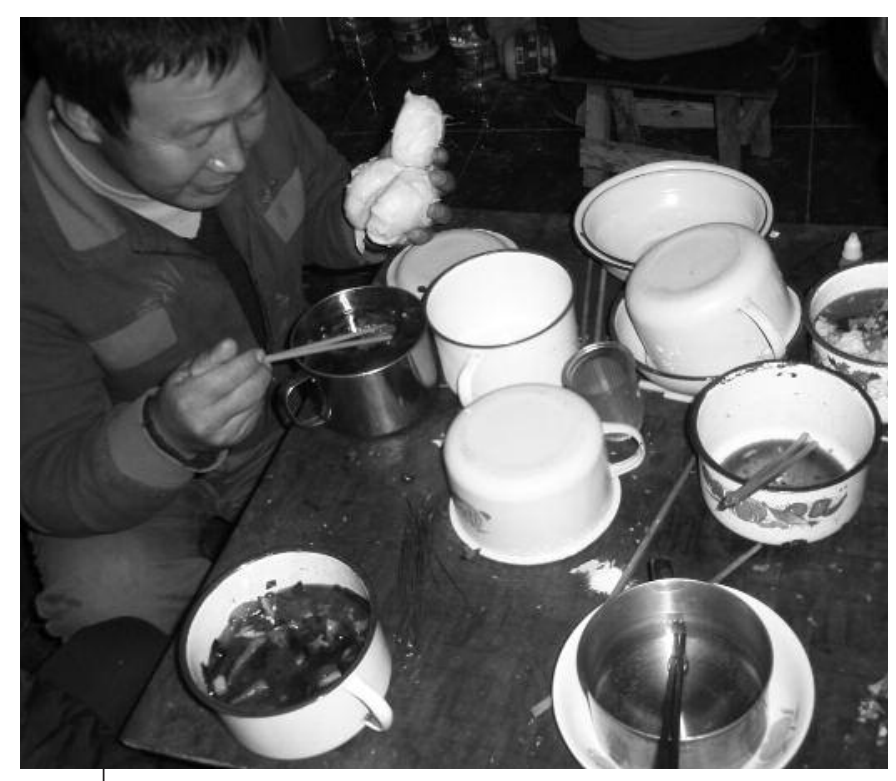

Daily meal of a worker

(c) Pun Ngai and Xu Yi

form era, with "rule by law" used to defend an evolving constellation of property rights and class relations. Faith in the law is a political device to safeguard a changing political regime in the process of privatisation and liberalisation that has led to a rapid transfer of wealth and a reconfiguration of social class and status. Legalism has never been intended to support a culture of civic participation, and even less to protect labour rights. The workers had to learn this "truth" through their own actions.

The concepts of justice and law have nevertheless embodied different meanings when employed by workers. Using the term gongdao is a call for morality derived from a basic belief in human fairness embedded in the order of heaven and the cosmos. In the eyes of construction workers, gongdao is more basic and fundamental once it is challenged. Gongdao, with its faith rooted at the community level, is therefore a habitus concept, (24) while the concept of law, with its provisions by the state, is a formal legal concept. We found that workers made stronger claims under gongdao than under weifa, and that they were more angry when gongdao was transgressed.

Law is a new faith in Chinese society created by the Chinese state. As a new ideology, it occupies a key position in providing an understanding of the normative behaviours of social agents, be they peasants, workers, or bosses. However, if "building a legalised society" is a progressive attempt in the eyes of the Chinese elite, it is less so to peasants and workers, who understand their social lives through the principles of justice, humanity, and morality. To request an explanation - "Tao yi ge shuo fa" (讨一个说法) - a usage often employed when construction workers go to the office of the construction company demanding their delayed payments, is to ask for moral grounds rather than a legal rationale.

21. Ching Kwan Lee, Against the Law: Labour Protests in China's Rustbelt and Sunbelt, Berkeley, University of California Press, 2007

22. Mary E. Gallagher, Contagious Capitalism: Clobalization and the Politics of Labour in China, New Jersey, Princeton University Press, 2005

23. Ching Kwan Lee, op. cit., 2007.

24. "Habitus" refers to a set of socially learned dispositions, skills, and ways of acting that are often taken for granted, and that are acquired through the activities and experiences of everyday life. 


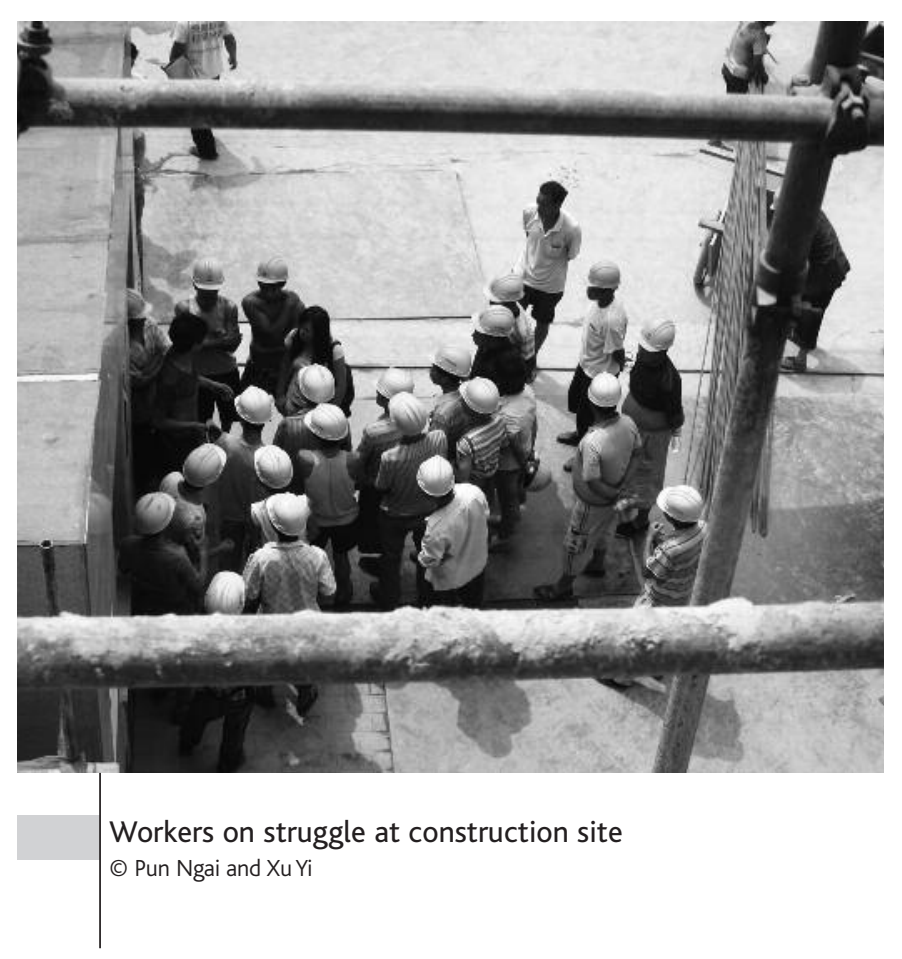

Workers are usually very anxious to receive their wages before they reunite with their families for the Chinese New Year.

As a mother of three children, Lan was less patient than the men in waiting for her delayed payment. She had been away from home for half a year working on the construction site, and her only reason for leaving her children was to earn money for her family. Working for no money was simply unacceptable. Taking action to demand their money was morally legitimate, whether legal or illegal. She further complained,

A group of Henan workers took action to fight for their wages yesterday. Why do we still have to wait? Wait for what? The Henan workers threatened to damage the villas they built and surrounded the office of the contractor on the construction site and didn't allow the office staff to leave. The staff then called the police and two police cars came. The manager of the company finally showed up and promised to pay the workers three days later....But how about us? We haven't managed to nao [i⿵门⿱亠巾禸 - literally means to make noise and create a disturbance]! How can we get our wages!

Arguments and fighting were a frequent phenomenon on the construction site. Workers called for nao instead of legal means to resolve their labour disputes. The tense relationship between subcontractors and workers often triggered violent acts arising from verbal disagreements. On several occasions we observed severe fighting, usually collective, between workers and their subcontractor, or between the subcontractor and his workers against their contractor, or sometimes between different subcontract teams over work conflicts on the construction site. One case we observed was in December 2008, when a subcontractor called 20 of his workers to surround the office of his contractor to demand a delayed payment. This ended up in collective fighting when the contractor called in his own hired hands. Workers on both sides were injured.

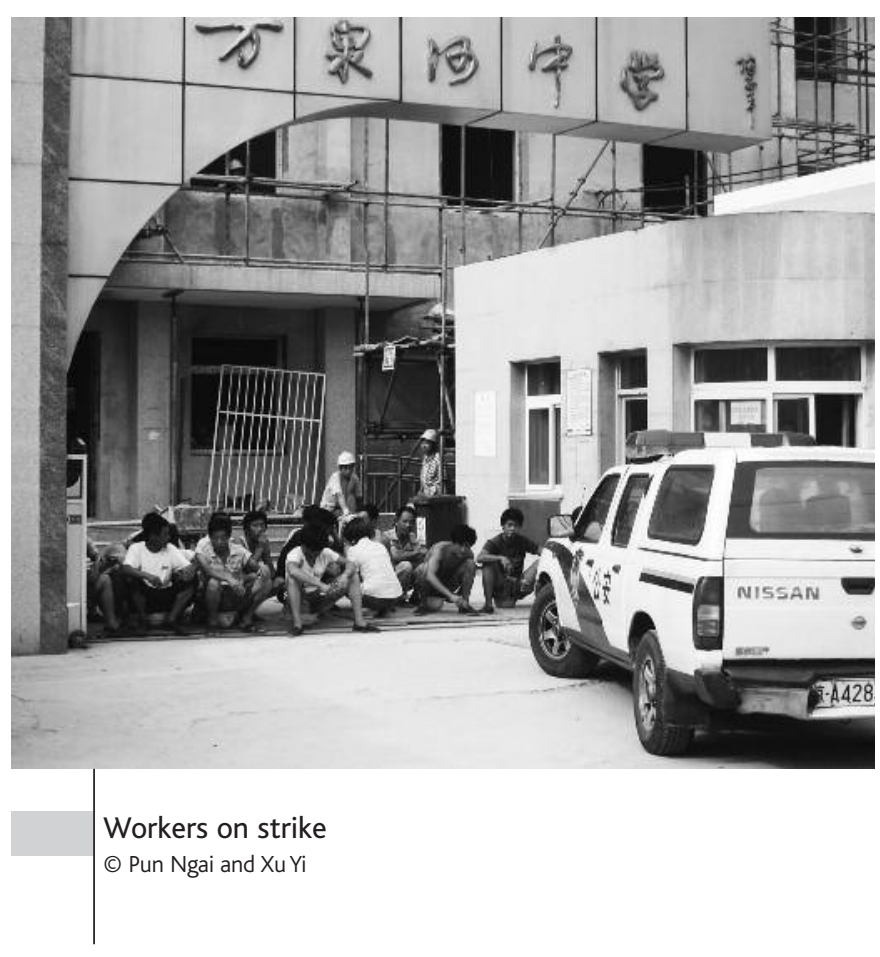

Lan's group had been told by their subcontractor that they would receive their wages on December 26. Some of her co-workers had already bought train tickets, hoping to return home immediately after receiving their three months' payment. On December 29, the subcontractor came and said the company still had not paid him the money he needed to pay the workers. Since the New Year's holiday was imminent, the workers would have to wait until January 3. When January 3 arrived, the workers still had not seen their money. Anxiety and anger mounted.

One of her co-workers, Tin, jumped into the conversation:

We have to nao. We have to show our muscle. When we were working, they [the quality controllers sent by the contractor] came to monitor and fuss over our job. Every day we were watched. But now that our work is finished, we've been dumped. We are nobody. We have to nao to demand our wages!

Both in the city and in the village, nao, creating a disturbance, was the word most frequently used when workers talked of demanding delayed wages. Nao means action involving challenges to "face," breaking up a relationship, and disturbing social harmony by petitioning the manager's office, labour bureau, and construction ministry and, if need, by blocking national highways to gain media attention. Most workers labouring in the industry for a few years found no way to resolve their wage arrears other than nao, and nao therefore became a last resort, a weapon of the weak, and an act of rightful resistance. (25)

The bargaining power of workers became minimal once their work was completed and they were eager to return home. Staying on the construction site without work was like a punishment, and they still had to pay for

25. Kevin O'Brien and Li Lianjiang, Rightful Resistance in Rural China, New York and Cambridge, Cambridge University Press, 2006. 
their meals and other daily expenses. Waiting in the city hence meant a double loss: on the one hand they could not return home in time to help with the harvest, and on the other they were unable to earn money while paying for daily living costs.

Lan's co-workers insisted on taking action to back up their wage demands. The workers feared simply waiting: "What do we do if January 6 comes and the boss still has no money to pay us? We can't wait any more." The workers discussed the issue fiercely until they finally reached a consensus to visit the offices of the Construction Ministry and ask officials for help the next day. While some workers prepared a petition letter, others collected information about their contractor and evidence of their labour relationship with this contractor, while others tried to find the address of the Ministry. Three workers, including Tin, were chosen as representatives to meet with officials. It is common practice for the disadvantaged in need of help to request a meeting with government officials. Even so, this was recourse to official support beyond a sense of legal rationality. In the eyes of the construction workers, the responsibility of officials to "resolve the difficulties" (纾解民困) of ordinary people was what served as the grounds of official legitimacy.

The workers travelled three hours by bus to reach the Ministry building only to be told that they were at the wrong place; because they lacked a labour contract, they had to go to the Labour Bureau for help. It took another hour to reach the Labour Bureau, where staff directed them to the District Labour Bureau in accordance with bureaucratic protocol; the workers had to begin requesting assistance from the lowest level at their work location. Late that afternoon, the workers finally reached the district office, which was crowded with workers from other construction sites, all caught in the same impasse of wage arrears. Tin observed:

Some workers were squatting quietly in the corridor waiting to see the officials. Some, however, were very agitated, and shouted that if they still couldn't receive their wages, they would climb to the top of the building and jump off.

Workers from other groups applauded this suggestion and screamed loudly that only a suicide attempt would make the boss listen to them and repay them on the spot. "No boss has a conscience," or, "All bosses have the worst conscience" (黑心 - hei xin) were the most frequent utterances. Self-destructive action or violent protest is often threatened when construction workers see no way out. During the same month in 2009, at another construction site we visited, a worker climbed onto a bulldozer in a threat to commit suicide if his pay continued to be withheld. The construction company called the police, who arrived and ordered the worker to climb down while also asking the company to pay his delayed wages.

Other workers have been known to pick up axes and sledgehammers and damage the villas they built. In June 2008, a group of construction workers surrounded and wrecked a sales office as it prepared to welcome customers one morning. The workers yelled, "The company cares about customers, but not us!" This drew the attention of the property developer, who put pressure on the construction company to resolve the wage arrears.

Blocking a major highway in order to attract the attention of top officials in the central government was also a popular method of resistance. Only by disrupting urban life were the city's builders - these transient peasantworkers - able to secure their wages.
Tin and his co-workers were nevertheless still at the point of seeking redress by appealing to the authorities. He and his co-workers waited for an hour and a half to get in the door of the legal aid department of the District Labour Bureau. The first question put to them was whether they had a labour contract. They were told that if they did not, the Labour Department could not help them, as they did not have a legal employer, and hence did not have a legal labour relationship. Only if their labour relationship could be legally proven could workers request help from the Labour Bureau.

The staff of both the Construction Ministry and the District Labour Bureau knew that most workers in this industry are not given labour contracts. Tin asked, "If a labour contract is that important, why doesn't the government enforce it seriously? Why do none of us have contracts?" He felt very angry after being shuttled from one department to another. A hegemonic discourse on legalism was self-defeating, if not self-deceiving, in the eyes of the agitated workers. The workers finally learned that they were not protected by the law but excluded by it. As wage-labour, they were not recognised as "workers" simply due to the lack of a legally required written labour contract.

The failure to implement labour laws and disappointment toward the local government drove workers to the brink of violent action. When three of the workers returned to their construction site late that evening, they were unable to calm down and repeatedly proclaimed to their co-workers that if their money did not arrive, they had no choice but to fight: "It's not a normal industry! We workers have worked for no wage! ...If they don't give us our money, l'll lay down my life to fight them. How dare they refuse us our money?" But that evening Tin had not yet reached a point of pushing for actual violence. Instead, he began mobilising other workers to make a protest banner reading, "Return my money tainted with my blood and sweat!" (26) Such demonstrations were often one step away from physical conflict.

These acts of labour conflict were not isolated cases we observed at construction sites in Beijing and other cities. Rather, various efforts against wage arrears culminated in violent acts when the issue of non-payment became particularly severe at the end of the year. As a result, most of the workers we interviewed participated in collective action of some kind.

\section{Conclusion}

The struggle at the construction site - simply to fight for delayed wages - can be understood as a "bottom-line" struggle, as it exposes the nature of the subcontracting system and the failure of the politico-legal regime to protect the basic labour rights of migrant workers. Construction workers are well aware of the exploitative nature of the labour subcontracting system, because it often results in wage arrears and lack of compensation for bodily injury. During their struggles, the situation of "no boss" and hence "no labour relationship" is not a legal issue to them but rather a class issue disguised by legal discourse.

It is crystal clear that while the workers seldom use the word "class," they replace it with the language of justice and law. In short, the principle of injustice (bu gongdao) refers to unfair treatment by others who violate the minimum moral standards of society at large. A discourse of "rightful resistance" seems to overshadow the discourse of "class action," in that

26. The next morning, Tin and his co-workers launched a demonstration. After surrounding the management office for three hours, the workers were able to collect their delayed wages. 
workers make sense of their suffering in terms of an embedded morality rather than of class exploitation.

On deeper examination, however, we find that accusations of injustice lie at the very core of the capital-labour relationship, i.e., the production relation of the construction industry, which has been affected by rapid change in the nature and structure of the industry during the reform period. The political economy of "no boss" and "no labour relationship," a delinking of capital and industry and of management and labour, is also directly linked with the specific and exploitative nature of the labour subcontracting system. All labour struggles stem from this changing political economy of the construction industry.

It is not a "normal" industry for either subcontractors or workers, since there is no boss, and no employer who is directly responsible for their employment. The capital-labour relationship has been entirely disguised: the workers literally do not know the identity of the developers and construction companies who are ultimately responsible for the non-payment of wages owed to them. This mis-recognition has been made possible through a labour subcontracting system that sustains the valorisation of capital without always recompensing subsumed labour: an invisible hand, the market, operating several steps removed from the workforce, enables the dealing out of a rigged losing hand to a transient army of labour.

The specific practices involved in this rapidly changing construction industry induce angry, largely violent actions, sometimes a mixture of legal and non-legal collective action by construction workers. Actions taken by workers usually surface as a fight for legal labour rights, as the violation of their basic rights is legally sanctioned. This does not mean, however, that the minds of construction workers have been successfully indoctrinated with the hegemonic discourse of "a legalised society" or legalism. Rather, faith in legalism acts as a double-edged sword once workers discover that the law is not on their side. It collapses. Furthermore, workers learn that their basic labour rights are excluded rather than protected by law. In short, the labour subcontracting system is a core problem of the construction industry, generating a series of collective actions acted out not in legal but more in non-legal realms. When trust and faith in the law is lost, delayed payment becomes unacceptable, and the workers' consent breaks, resulting in militant labour action. 